\title{
OSTEORADIONEKROSIS PASCA EKSTRAKSI GIGI PASIEN DENGAN RIWAYAT
} KANKER NASOFARING

\section{Yayun Siti Rochmah*}

Keywords:

Osteoradionekrosis,

Radiotheraphy,

Dental extraction

\section{ABSTRACT}

Background: Osteoradionecrosis (ORN) post dental extraction is post dental extraction complication with post radiation cancer theraphy. Objective : to present rare case, ORN post dental extraction with post radiation Ca nasopharing therapy 3 years ago.

Case Management: A 54 years old patient reported to the dental out-patient department with a chief complaint of pus discharge from right buccal since post dental extraction 6 months ago. He gave a history of a nasopharing Carcinoma with histopatology as squamous cell carcinoms 3 years ago and radio therapy but no surgery. Intraoral examination, exposed necrotic bone found from right lower retromolar area 46 with pus discharge. Radiographic view was likely squester. Local surgical debridement and the sequestrectomy was undertaken with general anaesthesia. Antibiotic injection treatment was ceftriaxon $2 x 1 \mathrm{gram}$, infus metronidazol $3 \times 500 \mathrm{mg}$ and ketorolac $3 \times 1$ ampul, the patient was treated for 3 days and educated to maintain his oral hygiene with povidone iodine gargle.

Discussion: Osteoradionecrosis (ORN) is late effect of radiation therapy that results in irreversible tissue death, which is clinically observed as bony exposure for more than 3 months duration. The mandible is affected more often than the maxilla or any other bones of head and neck region. The incidence of ORN in the mandible is reported to be between $2 \%$ and $22 \%$ and most often affects the body of the mandible. Ideal time is one year minimal post radiotherapy to get maximal vascularization for optimal healing. But immunity factor and radiation doses can trigger emergense ORN.

Conclusion: Need time consideration, clinic analysis and pathologys before doing dental extraction for post radiotherapy cancer cases to prevent ORN.

\section{PENDAHULUAN}

Pencabutan gigi merupakan terapi yang paling sering dilakukan dalam kedokteran gigi. Pencabutan gigi harus memperhatikan indikasi dan kontra indikasi. Pemeriksaan secara detail kondisi fisik dan sistemik pasien sangat diperlukan untuk menghindari terjadinya komplikasi pasca pencabutan terutama riwayat imunitas dan hasil pemeriksaan patologi anatomi. Komplikasi post pencabutan gigi dapat terjadi sesaat, dapat juga terjadi beberapa lama setelah pencabutan. Penanganan komplikasi yang kurang tepat akan memperparah kondisi pasien bahkan dapat berakibat fatal bagi pasien terutama pasien dengan riwayat penyakit kanker. Jumlah kejadian kanker di seluruh dunia masih sangat tinggi dan terus meningkat seiring dengan perubahan pola hidup. Menurut data (WHO) tahun 2013, insiden kanker di dunia meningkat dari 12,7 juta kasus pada tahun 2008 menjadi 14,1 juta kasus tahun 2012. Pada tahun 2030 insiden kanker diperkirakan dapat mencapai 26 juta orang dan yang meninggal sekitar 17 juta. $^{1}$

Osteoradionekrosis (ORN) merupakan salah satu komplikasi pencabutan, dimana sering ditemui pada pasien post radioterapi

${ }^{\star}$ Departemen Bedah Mulut Fakultas Kedokteran Gigi Universitas Islam Sultan Agung

Korespondensi: yayun@unissula.ac.id 
yaitu berupa munculnya tulang yang nekrotik (squester) setelah dilakukan pencabutan gigi beberapa waktu. Prevalensi kejadian ORN pada terapi radiasi konvensional 7,4\%, IMRT (Intensity Modulated RadioTherapy) 5,1\%, Chemoradiotherapy $6,8 \%$, brachiteraphy $5,3 \%$. Resiko ORN akan meningkat bila dosis radiasi mencapai 6,000 cGy. ${ }^{2}$ Pada studi kohort 68 kasus ORN, 34 kasus (50\%) berhubungan dengan riwayat pencabutan gigi. ${ }^{2}$ ORN lebih sering didapatkan pada regio mandibula daripada maksila karena vaskularisasi mandibula lebih jelek daripada maksila. ${ }^{2}$ Untuk menghindari terjadinya ORN perlu dilakukan pemeriksaan secara lengkap baik subyektif maupun objektif dan mempertimbangkan waktu yang tepat dan aman untuk melakukan tindakan invasif pada pasien post radioterapi. ORN harus dibedakan antara ORN yang benar-benar terjadi karena efek radiasi atau merupakan suatu tumor yang rekuren. Karena gambaran radiologis suatu ORN dan rekurensi tumor sangat overlap. ${ }^{3}$

Tujuan penulisan makalah ini adalah mempresentasikan kasus ORN yang terjadi setelah terapi radiasi 3 tahun yang lalu dan hasil pemeriksaan PA yang berbeda dengan tumor primer.

\section{LAPORAN KASUS}

Pasien laki-laki berusia 54 tahun datang dengan keluhan rahang nya sakit kadangkadang dan keluar nanahnya sejak setelah dilakukan pencabutan gigi 6 bulan yang lalu. Pekerjaan sebagai PNS dan mempunyai 5 anak. Tempat tinggal di area industri yang padat penduduk. Pasien ada riwayat kanker nasofaring 3 tahun yang lalu dengan hasil biopsi histopatologi squamous sel karsinoma. Pasien sudah selesai menjalani radioterapi 23 kali tanpa pembedahan dan sudah dinyatakan terapi selesai. Pada 3 bulan yang lalu pasien mencabutkan giginya yang berlubang di puskesmas, tetapi setelah dilakukan pencabutan, muncul rasa sakit yang hilang timbul dan keluar nanah.

Pemeriksaan ekstraoral : tidak ada kelainan, tidak ada fistel. Pemeriksaan intraoral, tampak tulang nekrotik (sequester) yang dikelilingi dengan pus pada regio 45,46, gingiva sedikit kemerahan, nyeri tekan. (Gambar 1A)

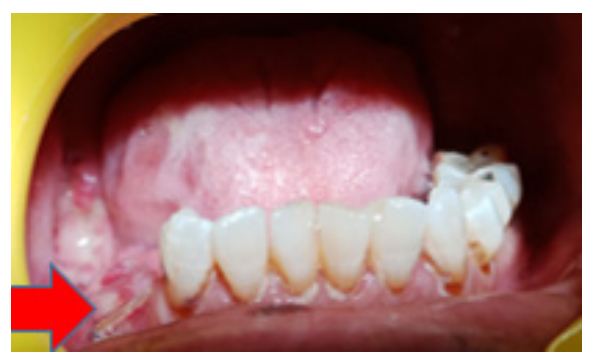

Gambar 1 A : Gambaran klinis

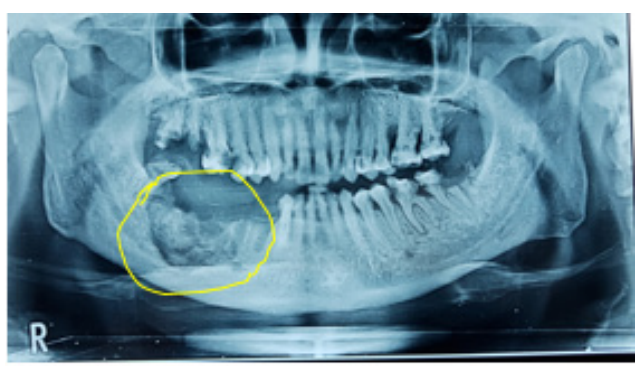

Gambar 1 B : Gambaran radiologis

Hasil foto panoramik : tampak gambaran sequester pada regio 45,46,47 (gambar 1B)

Terapi : pasien dilakukan debridement dan sequesterectomy dengan general anestesi dan hasil operasi dikirim ke laboratorium patologi anatomi dengan hasil adenoma phleomorphic dan diberikan terapi injeksi antibiotika ceftriaxon 2x1 gram, infus metronidazol 3x500 mg dan ketorolac $3 \times 1$ ampul, pasien dintruksikan untuk menjaga oral hygiene dengan chlorheksidin sehari $3 x$ serta roborontia berupa vitamin E (Tokoferol) untuk merangsang pembentukan pembuluh darah baru. Pasien dirawat inap selama 3 hari dan dipulangkan dengan obat 
antibiotika dan analgesik per oral. Pasien disarankan untuk dilakukan terapi hiperbarik untuk memaksimalkan proses penyembuhan. Hasil pemeriksaan histopatolgi jaringan post operasi : adenoma pleomorphic.

\section{DISKUSI}

Osteoradionekrosis (ORN) merupakan komplikasi yang sering terjadi pada pasien post ekstraksi gigi dengan riwayat radioterapi. Biasanya diagnosa ORN beberapa saat post radioterapi. Beberapa referensi menyebutkan durasi minimal 6 bulan post radioterapi, apabila ingin melakukan pencabutan untuk memberi kesempatan perbaikan vaskularisasi pasca radioterapi, sehingga ORN dapat dihindari. ${ }^{4}$ Radioterapi dapat menimbulkan efek hipoksia, hipovaskularisasi, hiposeluler sehingga akan menurunkan kemampuan untuk remodeling pasca terjadi injury. Keadaan ini akan diikuti dengan kerusakan tulang yang progresif dan akan digantikan dengan munculnya rekurensi tumor. Resiko ORN dapat muncul dengan berbagai faktor penyebab diantaranya oral hygiene yang jelek, invasi sel tumor pada tulang, penyakit sistemik serta jenis radiasi yang digunakan. ${ }^{4}$

Pada kasus ini pasien mengalami ORN setelah dilakukan pencabutan gigi 3 bulan yang lalu dengan riwayat radioterapi sampai 23 kali dengan riwayat karsinoma nasofaring sejak 3 tahun yang lalu. Saat itu pasien tidak dilakukan tindakan bedah karena ukuran tumor masih kecil dan cukup dilakukan tindakan radioterapi. Pasien rutin melakukan kontrol untuk evaluasi rekurensi dan metastasis dengan bone scan dan dinyatakan bersih dari sel tumor. Berdasarkan jarak terapi radiasi terakhir dan pencabutan sebenarnya sudah aman dan kecil kemungkinan terjadi ORN. Tetapi pada pasien ini tetap terjadi ORN, hal ini dapat disebabkan karena kondisi psikis pasien yang sejak divonis terkena kanker agak sedikit mudah stres dan emosi. Stres dapat berpengaruh pada respon imun, termasuk aktifitas NK sel dan produksi interferon. ${ }^{5}$ Stres berpengaruh terhadap respon sel NK pada sitokin. Apabila respon NK sel terhadap sitokin menurun, maka akan mempengaruhi kemampuan membunuh dari sel killing terhadap sel tumor atau sel yang terinfeksi virus. Sel NK dan sel T sitotoksik diatur oleh stres dan mempengaruhi progresifitas tumor melalui hubungan ekspresi MHC 1 (Major Histocompatibility Complex), produksi interferon dan pelepasan protein perforin apoptosis, granzyme A, B dan Fasl. Respon tersebut tergantung dengan level stres yang dialami seseorang. Stres dapat merangsang proses karsinogenesis. Stres dapat menyebabkan perubahan apoptosis yang merangsang perkembangan sel malignan. ${ }^{5,6}$ Pasien ini pekerjaannya sebagai pegawai negeri dengan 5 anak yang sedang menjalani kuliah semua di perguruan tinggi. Pasien mengaku terlalu stres dalam mencoba memenuhi kebutuhan ekonomi terutama masalah biaya kuliah. Hal ini dapat sebagai penyebab munculnya OSN. Pada pasien ini dilakukan debridement dan sequesterectomy dengan general anestesi dan terapi injeksi antibiotika. Post operasi pasien dilakukan terapi hiperbarik selama 1 bulan seminggu sekali. Hal ini bertujuan untuk merangsang proses vaskularisasi dan penyembuhan luka lebih optimal. Terapi oksigenasi (hiperbarik oksigen) menjaga homeostatik jaringan dan penyembuhan luka dan merangsang integritas jaringan lunak dan tulang. ${ }^{7}$ HBO sangat efisien dalam merangsang angiogenesis dan aktivitas fibroblast. Berdasarkan teori, tulang atau jaringan yang nekrosis pada ORN merupakan hasil deregulasi aktifitas fibroblas akibat radiasi 
yang menyebabkan efek radikal bebas pada kerusakan mikrovaskuler, sel osteogenik dan fibroblas. ${ }^{7}$ Tumor nasofaring banyak dilaporkan sebagai tumor primer munculnya ORN. ${ }^{8}$ Demikian juga pada pasien ini juga dengan riwayat tumor nasofaring.

Penggunaan antibiotika dalam terapi ORN dilaporkan mampu menurunkan komplikasi $1.9 \%$ dan $5.8 \%$ resiko penyembuhan tertunda. Antibiotika pre ekstraksi pada pasien post radiasi mampu menurunkan resiko ORN. Penelitian pada 57 pasien post radiasi yang dilakukan ekstraksi dan diberikan antibiotika sebelum tindakan, maka pasien yang mengalami ORN hanya satu orang. ${ }^{8}$ Pemberian antibiotika profilaksis dan pemakaian obat kumur sejak seminggu sebelum tindakan mampu meminimalisir terjadinya ORN pasca pencabutan pada pasien post radiasi. Hasil akan lebih baik lagi bila ditambahkan dengan terapi hiperbarik oksigen. ${ }^{9}$ Pemberian pentofilin dan tokoferol pasca ekstraksi akan memperbaiki vaskularisasi pasca ekstraksi pada pasien pasca radioterapi.

\section{KESIMPULAN}

Pertimbangan waktu, analisis klinis dan patologis diperlukan sebelum melakukan ekstraksi gigi pada kasus post radioterapi kanker untuk mencegah terjadinya ORN. Penanganan ORN yang benar akan mempercepat proses penyembuhan.

\section{DAFTAR PUSTAKA}

1. Siwi Setya Utami, Mustikasari, aspek psikososial pada penderita kanker payudara: studi pendahuIuan, Jurnal Keperawatan Indonesia, Volume 20 No.2, Juli 2017, hal 65-74

2. Douglas E. Peterson \& Wolfgang Doerr \& Allan Hovan \& Andres Pinto \& Debbie Saunders \& Linda S. Elting \& Fred K. L. Spijkervet \& Michael T. Brennan, Osteoradionecrosis in cancer pa- tients: the evidence base for treatment-dependent frequency, current management strategies, and future studies, Support Care Cancer (2010) 18:1089-1098

3. Martin José C.,Hilgenberg A., Santos Frederico K., Management of Patients with Osteoradionecrosis of the after Radiation Therapy to the Head and Neck, Intl. Arch. Otorhinolaryngol., São Paulo, v.12, n.2, p. 239-245, 2008.

4. L. Alhilali, A.R. Reynolds, and S. Fakhran, Osteoradionecrosis after Radiation Therapy for Head and Neck Cancer:Differentiation from Recurrent Disease with CT and PET/CTImaging, AJNR Am J Neuroradiol 35:1405-11 Jul 2014

5. Nak Kym S and Bo Yeon K., Psychological stress and cancer, Journal of Analytical Science and Technology, Springers (2015), 6:30.

6. Jan-Dirk Raguse,Jaber Hossamo, Ingeborg Tinhofer, Bodo Hoffmeister, Volker Budach, et al, Patient and treatment-related risk factors for osteoradionecrosis of the jaw in patients with head and neck cancer, Oral Surgery Oral medicine Oral Pathology Oral Oral Radiology Journal March 2016 Volume 121, Issue 3, Pages 215221.

7. Saleh A. Al-Bazie, Mesaad Bahatheq1, Mohamad Al-Ghazi1, Nasser Al-Rajhi1, Sundar Ramalingam, Antibiotic protocol for the prevention of osteoradionecrosis following dental extractions in irradiated head and neck cancer patients: A 10 years prospective study, Journal of Cancer Research and Therapeutics - April-June 2016 Volume 12 - Issue 2.

8. Ravindran Rathy, S. Sunil, and M. Nivia, Osteoradionecrosis of mandible: Case report with review of literature, Contemp Clin Dent. 2013 AprJun; 4(2): 251-253.

9. Sultan A., Hanna G., Danielle NM, Chau N.,Goguen,Marty B., Guilherme R., Jonathan d. schoenfeld, et al., The Use of Hyperbaric Oxygen for the Prevention and Management of Osteoradionecrosis of the Jaw: A Dana-Farber/Brigham and Women's Cancer Center Multidisciplinary Guideline, TheOncologist 2017;22:343-350. 